\title{
The inhibitory effect of serum on the growth of Torulopsis glabrata
}

\author{
M. A. PETROU and T.R. ROGERS \\ Department of Medical Microbiology, Charing Cross and Westminster Medical School, 17, Horseferry Road, \\ London SW1P 2AR
}

\begin{abstract}
Summary. Normal human plasma and serum were found to inhibit the growth of Torulopsis glabrata and, to a lesser extent, other yeasts. The factor responsible for the inhibition of $T$. glabrata was not dialysable, was heat stable at $56^{\circ} \mathrm{C}$ for up to $4 \mathrm{~h}$ and could be partly removed by absorption with viable $T$. glabrata but not Candida albicans. It was fungistatic at low concentrations and fungicidal at high concentrations, stable up to 4 years between $-20^{\circ} \mathrm{C}$ and $-70^{\circ} \mathrm{C}$, but for only a few weeks at $4^{\circ} \mathrm{C}$. Studies with Cohn fractions of serum showed that the inhibitory components were in either the alpha or beta globulin fraction or both. The combined effects of transferrin and IgM accounted for about $70 \%$ of the total inhibition observed. We were unable to identify the component responsible for the residual inhibition of growth. The inhibitory effect was totally neutralised by tetracyclines, quinolones, sulphamethoxazole and by very low concentrations of polyenes, imidazoles and 5-fluorocytosine.
\end{abstract}

\section{Introduction}

Transferrin was first identified as an iron binding serum protein (Schade and Caroline, 1946) and it inhibits many species of fungi, including yeasts, by iron-chelation that can be demonstrated in vitro and is reversible by the addition of high concentrations of iron to serum-containing media (Caroline et al, 1964; Summers and Hasenclever, 1964; Esterly et al., 1967; King et al., 1975; Otto and Howard, 1976). Moreover, the elevated serum iron concentrations that follow multiple blood transfusions can also contribute to the loss of natural immunity to infection with these organisms by neutralising the inhibitory effect of transferrin (Caroline et al., 1969).

Inhibition of $T$. glabrata by normal serum has been reported previously (Summers and Hasenclever, 1964; Howard and Otto, 1967; Otto and Howard, 1976). We have also observed that $T$. glabrata was inhibited in media containing $10 \%$ human serum (Petrou and Rogers, 1985); and we found that growth was restored in the presence of some antibiotics and subinhibitory concentrations of antifungal drugs. These findings led us to investigate whether or not transferrin is the sole serum factor inhibitory to clinically important yeasts, with particular reference to $T$. glabrata which is especially susceptible to the effects of serum (Otto and Howard, 1976). We also attempted

Received 9 Feb. 1987; revised version accepted 15 June 1987. to characterise the components of the inhibitory factor and the possible mechanism by which drugs neutralise its effects.

\section{Materials and methods}

\section{Organisms}

Thirty two yeasts from patients in receipt of or awaiting bone marrow transplantation were employed; they were stored in $10 \%$ glycerol at $-70^{\circ} \mathrm{C}$ as the Westminster Children Collection (WCC). Three strains from the National Collection of Pathogenic Fungi, Colindale (NCPF)-T. glabrata no.3240, Saccharomyces cerevisiae no. 3178 and $C$. tropicalis no. $3111-$ were also used. The yeasts were identified with the API 20C auxanogram system (API Laboratory Products Ltd, Farnborough, Hants, GU14 7QH) and grouped according to their susceptibility to human serum (table I).

\section{Plasma and serum}

Plasma was from healthy blood transfusion donors, and serum was from donors on their first visit to an antenatal clinic as well as from healthy volunteers. The antenatal sera gave results identical to sera from healthy volunteers and both groups will be referred to as normal sera. Other normal sera that had been stored at $-20^{\circ} \mathrm{C}$ or $-70^{\circ} \mathrm{C}$ for up to 4 years, and plasma or serum that had been kept at $4^{\circ} \mathrm{C}$ for up to 6 months, were also used. The inhibitory activity of sera with different immunoglobulin concentrations was studied with three cord sera (substantially deficient in IgM), 10 from patients with 
Table I. Distribution of yeasts according to their susceptibility to human serum incorporated into YNB agar medium

\begin{tabular}{|c|c|c|c|}
\hline Group & $\begin{array}{l}\text { Percentage of } \\
\text { serum needed } \\
\text { for inhibition } \\
\text { of growth* }\end{array}$ & Organisms & $\begin{array}{l}\text { Number of } \\
\text { strains tested }\end{array}$ \\
\hline 1 & $2 \cdot 5$ & T. glabrata & 12 \\
\hline 2 & $20 \cdot 0$ & $\begin{array}{l}\text { S. cerevisiae } \\
\text { Cr. neoformans }\end{array}$ & $\begin{array}{l}3 \\
1\end{array}$ \\
\hline 3 & $30 \cdot 0$ & $\begin{array}{l}\text { C. pseudotropicalis } \\
\text { C. parapsilosis } \\
\text { Rhodotorula rubra } \\
\text { Cr. laurentii }\end{array}$ & $\begin{array}{l}2 \\
2 \\
2 \\
1\end{array}$ \\
\hline 4 & $50 \cdot 0$ & $\begin{array}{l}\text { T. maris } \\
\text { C. krusei } \\
\text { T. candida }\end{array}$ & $\begin{array}{l}1 \\
2 \\
1\end{array}$ \\
\hline 5 & No inhibition & $\begin{array}{l}\text { C. albicans } \\
\text { C. tropicalis } \\
\text { C. guilliermondii }\end{array}$ & $\begin{array}{l}4 \\
2 \\
2\end{array}$ \\
\hline
\end{tabular}

* Inhibition so that no colonies were visible to the unaided eye after incubation for $48 \mathrm{~h}$ at $37^{\circ} \mathrm{C}$.

$\operatorname{IgG}$ myeloma paraprotein and normal $\operatorname{IgA}$ and $\operatorname{IgM}, 10$ with IgM myeloma paraprotein and normal IgG and IgA, one substantially deficient of IgG, IgA and IgM (all $<0.01 \mathrm{~g} / \mathrm{L}$ ) but with a normal transferrin concentration, and one serum substantially deficient of $\operatorname{IgA}(<0.01 \mathrm{~g} / \mathrm{L})$ but normal IgG, IgM and transferrin levels. Normal range refers to levels of immunoglobulin within the range acceptable in our immunology laboratory, according to the age of the donor, and normal transferrin concentrations were between 2 and $4 \mathrm{~g} / \mathrm{L}$. As no differences were found between plasma and serum, only the results with serum are given.

\section{Serum proteins}

Human transferrin, pure substance (Sigma Chemical Co., St Louis, MO, USA); human gammaglobulin Cohn fraction II (Sigma); human $\alpha$ and $\beta$ globulin Cohn fraction IV 1 (Sigma); and human serum albumin (Flow Laboratories, Uxbridge), were dissolved in phosphate buffered saline (PBS; $\mathrm{NaCl} 0.8 \% \mathrm{w} / \mathrm{v}, \mathrm{K}_{2} \mathrm{HPO}_{4} 0.12 \%$ $\left.\mathrm{w} / \mathrm{v}, \mathrm{KH}_{2} \mathrm{PO}_{4} 0.03 \% \mathrm{w} / \mathrm{v}, p \mathrm{H} 7.3 \pm 0 \cdot 1\right)$ to a concentration equivalent to that in normal serum. The final concentrations of serum proteins in stock solutions were determined as described by Whicher and Perry (1984) with nephelometry (Beckman ICS System, Beckman, High Wycombe).

\section{Drugs}

Those used were either pure substance or intravenous preparations and were dissolved according to the manufacturers' instructions. They included antibacterial, antifungal and other drugs (table II). Each drug was tested at concentrations of $0.1,0.5,1,5,10,25,50$ and
Table II. The drugs tested and their effect on the inhibitory factor in $10 \%$ serum

\begin{tabular}{|c|c|c|}
\hline $\begin{array}{l}\text { Drugs which } \\
\text { neutralise IF }\end{array}$ & $\begin{array}{c}\text { Minimum } \\
\text { concentration } \\
\text { needed, } \mathrm{mg} / \mathrm{L}\end{array}$ & $\begin{array}{c}\text { Drugs with } \\
\text { no effect } \\
\text { (at } 100 \mathrm{mg} / \mathrm{L} \text { ) }\end{array}$ \\
\hline $\begin{array}{l}\text { Quinolones: } \\
\text { Ciprofloxacin } \\
\text { Enoxacin } \\
\text { Nalidixic acid } \\
\text { Norfloxacin }\end{array}$ & $\begin{array}{r}10 \\
10 \\
5 \\
10\end{array}$ & $\begin{array}{l}\text { Aminoglycosides: } \\
\text { Amikacin } \\
\text { Gentamicin } \\
\text { Netilmicin } \\
\text { Sissomicin } \\
\text { Streptomycin } \\
\text { Tobramycin }\end{array}$ \\
\hline $\begin{array}{l}\text { Tetracyclines: } \\
\text { Doxycycline } \\
\text { Minocycline } \\
\text { Tetracycline-HCl }\end{array}$ & $\begin{array}{r}10 \\
5 \\
5\end{array}$ & $\begin{array}{l}\text { Cephalosporins: } \\
\text { Cephalexin } \\
\text { Cephradine } \\
\text { Cefuroxime } \\
\text { Cefsulodin } \\
\text { Cefotaxime } \\
\text { Latamoxef } \\
\text { Ceftazidime }\end{array}$ \\
\hline $\begin{array}{l}\text { Polyenes: } \\
\text { Amphotericin B } \\
\text { Mepartricin } \\
\text { Nystatin } \\
\text { Partricin }\end{array}$ & $\begin{array}{l}0 \cdot 01 \\
0 \cdot 01 \\
0 \cdot 01 \\
0 \cdot 01\end{array}$ & $\begin{array}{l}\text { Penicillins: } \\
\text { Benzylpenicillin } \\
\text { Ampicillin } \\
\text { Carbenicillin } \\
\text { Temocillin } \\
\text { Ticarcillin } \\
\text { Mezlocillin } \\
\text { Azlocillin } \\
\text { Piperacillin }\end{array}$ \\
\hline $\begin{array}{l}\text { Imidazoles: } \\
\text { Bifonazole } \\
\text { Clotrimazole } \\
\text { Econazole } \\
\text { Isoconazole } \\
\text { Ketoconazole } \\
\text { Miconazole }\end{array}$ & $\begin{array}{l}0.06 \\
0.06 \\
0.06 \\
0.06 \\
0.06 \\
0.06\end{array}$ & $\begin{array}{l}\text { Other drugs: } \\
\text { Chloramphenicol } \\
\text { Colistin } \\
\text { Erythromycin } \\
\text { Fusidic acid } \\
\text { Rifampicin } \\
\text { Cyclosporin A } \\
\text { Hydrocortisone } \\
\text { Methotrexate } \\
\text { Methylprednisolone }\end{array}$ \\
\hline $\begin{array}{l}\text { Other drugs: } \\
\text { Sulphamethoxazole } \\
\text { 5-fluorocytosine }\end{array}$ & $\begin{array}{c}50 \\
0.03\end{array}$ & \\
\hline
\end{tabular}

$100 \mathrm{mg} / \mathrm{L}$ with the exception that the antifungal drugs were used in subinhibitory concentrations.

\section{Heat inactivation}

Volumes of pooled serum were placed at $56^{\circ} \mathrm{C}$ and triplicate samples removed at various time intervals up to $4 \mathrm{~h}$. The samples were rapidly brought to room temperature before use. Serum was heated to $56^{\circ} \mathrm{C}$ for $30 \mathrm{~min}$ to inactivate complement.

\section{Dialysis}

Samples of serum $(6-10 \mathrm{ml})$ were placed individually in pre-treated dialysis tubing which had a molecular 
weight exclusion limit of approximately 10000 and were dialysed against $4 \mathrm{~L}$ of PBS for $36 \mathrm{~h}$ at $4^{\circ} \mathrm{C}$, the PBS being changed twice. After dialysis the sera were heatinactivated and tested for inhibitory activity.

\section{Absorption of the inhibitory factor}

Serum (inactivated and non-inactivated) was incubated at $37^{\circ} \mathrm{C}$ and $4^{\circ} \mathrm{C}$ for 1,4 and $24 \mathrm{~h}$ with an inoculum of $10^{6} \mathrm{cfu} / \mathrm{ml}$ of $T$. glabrata or C. albicans. After incubation the yeast cells were removed either by centrifugation at $2500 \mathrm{~g}$ for $20 \mathrm{~min}$ or by membrane filtration (Flow Filtration System).

\section{Selective depletion of transferrin and Ig $M$ from serum}

Transferrin and IgM were individually absorbed from serum with anti-human transferrin and anti-IgM antibodies attached to sepharose particles. The affinity matrix was prepared from cyanogen bromide-activated Sepharose 4B and rabbit antisera, by the method of King et al., (1975). All the separations were performed in $0.1 \mathrm{M}$ Tris buffer, $p \mathrm{H} 7.4$ or $p \mathrm{H} 8.0$, containing $0.5 \mathrm{M} \mathrm{NaCl}$.

\section{Growth medium}

Yeast Nitrogen Base (YNB) (Wickerham, 1951) with added glucose and L-asparagine, was used both in its commercial form (Difco Laboratories, Detroit, MI) as well as being prepared from individual components to exclude essential elements such as iron $(\mathrm{Fe})$ magnesium $(\mathrm{Mg})$, copper $(\mathrm{Cu})$ or manganese $(\mathrm{Mn})$. The medium was prepared as a 10 -fold concentrate and the $p \mathrm{H}$ adjusted to $4.8,6.0,7.2$ or 8.0 before filter sterilisation. Media solidified with $2 \%$ agar included YNB, Mueller-Hinton Agar (MHA ; Oxoid), Brain Heart Infusion Agar (BHIA; Oxoid) and Sabouraud's Dextrose Agar (SDA; Oxoid).

\section{Liquid cultures}

These were grown at $37^{\circ} \mathrm{C}$ in an orbital shaker incubator (New Brunswick Scientific, Edison, NJ, USA) at $230 \mathrm{rpm}$, to a final concentration of $T$. glabrata WCC strain no. $08310^{5} \mathrm{cfu} / \mathrm{ml}$. The cultures included: (a) YNB at the four $p \mathrm{H}$ values; (b) $\mathrm{YNB}, p \mathrm{H} 7 \cdot 2$, without $\mathrm{Mg}, \mathrm{Fe}$, $\mathrm{Cu}$ or $\mathrm{Mn}$; (c) $\mathrm{YNB}, p \mathrm{H} 7 \cdot 2$, with serum (non-inactivated, and with the inhibitory factor absorbed) $10 \%$ or $20 \%$; (d) $\mathrm{YNB}, p \mathrm{H} 7 \cdot 2$, with added serum proteins; and (e) cultures in $100 \%$ serum. Decimal-dilution and plate-count techniques were used to estimate the viable counts at 24 and $48 \mathrm{~h}$ with Triton-X-phosphate buffer $(p \mathrm{H} \mathrm{7 \cdot 2,} \mathrm{BDH}$ Chemicals Ltd, Poole) as diluent and SDA plates.

\section{Experiments on solid media}

YNB with and without any of the four metals, was added to sterile water agar at $56^{\circ} \mathrm{C}$. Serum or serum proteins were added as necessary to ensure a range of concentrations. MHA, BHIA and SDA were also used with and without $10 \%$ or $20 \%$ serum. After pouring triplicate samples, the plates were dried and inoculated with a Denley multipoint inoculator (A 400, Denley Instruments Ltd, Sussex) which delivered $1 \mu \mathrm{l}$ of an inoculum of $10^{5} \mathrm{cfu} / \mathrm{ml}$. The results were recorded after incubation for 2 days at $37^{\circ} \mathrm{C}$ and scored as + for full growth, \pm partial growth and - for no growth.

\section{Radial diffusion assay of the inhibitory factor}

Melted YNB agar $(60 \mathrm{ml})$, cooled to $45^{\circ} \mathrm{C}$, was seeded with an overnight culture of $T$. glabrata WCC strain no. 083 , to yield a final cell concentration of $2 \times 10^{5} \mathrm{cfu} / \mathrm{ml}$, and poured into a $100 \mathrm{~mm}$ square petri dish. Wells of $8 \mathrm{~mm}$ diameter for a $0 \cdot 2-\mathrm{ml}$ capacity and $5 \mathrm{~mm}$ diameter for one of $0.1 \mathrm{ml}$ were cut. Serum, serum dilutions, or serum proteins were added to each well. After overnight incubation at $37^{\circ} \mathrm{C}$ the zone diameters were measured. With the exception of cord sera, all samples were tested in triplicate.

\section{The effect of ferric iron on the medium and the inhibitory factor}

Ferric iron $1 \mathrm{M}$, in the form of either ferric chloride (FC), ferric ammonium citrate (FAC) or ferric nitrate (FN) was added to iron-free Wickerham's YNB, $p \mathrm{H} \mathrm{7.2,}$ to achieve iron concentrations of $1 \cdot 23$ (as in YNB, Difco), $10,25,50,100,250,500$ and $1000 \mu \mathrm{M}$. During the addition of iron, the $p \mathrm{H}$ was tested with an EIL $p \mathrm{H}$ meter model 7010 (Electronic Instruments Ltd, Chertsey, Surrey), and the medium was used at the final $p \mathrm{H}$. For FC-containing liquid medium, the $p \mathrm{H}$ was also adjusted to $p \mathrm{H} 7.2$ by adding measured amounts of $1 \mathrm{M} \mathrm{NaOH}$. For solid media, a fixed volume of $\mathrm{NaOH}$ was added to bring the $p \mathrm{H}$ of the FC-containing medium to $7 \cdot 2$. The final $p \mathrm{H}$ of the plates was then checked with a glass flathead electrode in conjunction with a calomel reference electrode. Serum or transferrin was added to liquid and solid media to give a concentration of $10 \%$ when required.

\section{Serum and transferrin titration}

Either serum or transferrin $(100 \%$ serum-equivalent) was added to sterile $\mathrm{YNB}$ agar, $p \mathrm{H} 7 \cdot 2$, at $56^{\circ} \mathrm{C}$ to obtain concentrations of $0,0 \cdot 1,0 \cdot 5,1,2 \cdot 5,5,10,20,30,40$ and $50 \%$ (final concentration of agar was $2 \%$ ). After drying, the plates were inoculated, incubated as before and the results recorded after 1 and 2 days.

\section{Indirect tests of the effect of the inhibitory factor on the medium components}

The dialysis tubing, which was boiled twice for $10 \mathrm{~min}$ in sterile deionised distilled water, was cut open and placed on agar medium to cover either all or half of a dry

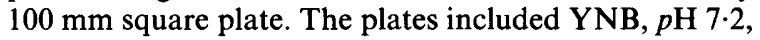
or $\mathrm{YNB}, p \mathrm{H} 7 \cdot 2$, with either serum or serum proteins. 
The plates with and without the membrane were either left uncovered or overlayed with a very thin film of 1 or $2 \%$ water agar. The two areas of the half-covered plates were inoculated with the 12 strains of $T$. glabrata and the effect on growth on the two sides was compared. The plates which were completely covered by the membrane were inoculated with all the yeasts and growth compared with that on plates without the membrane after incubation for 2 days at $37^{\circ} \mathrm{C}$.

\section{The effect of drugs on the inhibitory factor}

Agar mixtures containing $\mathrm{YNB}, p \mathrm{H} 7 \cdot 2$, or $\mathrm{YNB}$, $p \mathrm{H} 7 \cdot 2$, with $10 \%$ serum were distributed in $19 \cdot 5-\mathrm{ml}$ portions in sterile $25-\mathrm{ml}$ glass bottles. Each bottle received $0.5 \mathrm{ml}$ of an appropriate drug dilution to yield the concentration required, whereas the controls received $0.5 \mathrm{ml}$ of sterile drug solvent at the highest concentration used with the drug. After drying, the plates were inoculated, incubated and the results recorded as before.

\section{Results}

\section{Growth media and medium $p H$}

The four media tested supported the growth of all the yeast strains (tables III and IV). The more acidic the medium the faster the culture entered the stationary phase, and the viable counts were slightly higher than in media with basic $p H$ (table III). Wickerham (1951) medium was employed because its defined chemical composition facilitated use with omission of essential elements. $\mathrm{Mg}$ was found to be the only metal needed for growth by many strains at concentrations higher than those found in impurities; $\mathrm{Fe}, \mathrm{Cu}$ and $\mathrm{Mn}$ were needed at concentrations only slightly higher than in impurities for full growth (tables V and IV).

Table III. Effect of $p \mathrm{H}$ on the growth of $T$. glabrata in the presence or absence of serum

\begin{tabular}{|c|c|c|c|}
\hline \multicolumn{2}{|r|}{ YNB medium } & \multicolumn{2}{|c|}{ Viable count, cfu (SD)/ml at } \\
\hline$p \mathrm{H}$ & $\begin{array}{l}\text { inactivated serum } \\
\text { concentration }(\%)\end{array}$ & $24 \mathrm{~h}$ & $48 \mathrm{~h}$ \\
\hline \multirow[t]{2}{*}{$4 \cdot 8$} & 0 & $2.3(1.9) \times 10^{9}$ & $5.0(1.4) \times 10^{10}$ \\
\hline & 10 & $2.9(1 \cdot 1) \times 10^{8}$ & $6.4(1.6) \times 10^{9}$ \\
\hline \multirow[t]{2}{*}{$6 \cdot 0$} & 0 & $1.9(0.6) \times 10^{9}$ & $3.8(1.2) \times 10^{10}$ \\
\hline & 10 & $8.4(0.9) \times 10^{6}$ & $2.7(0.5) \times 10^{8}$ \\
\hline \multirow[t]{2}{*}{$7 \cdot 2$} & 0 & $1.7(0.4) \times 10^{9}$ & $1.3(1 \cdot 3) \times 10^{10}$ \\
\hline & 10 & $2.5(1 \cdot 3) \times 10^{6}$ & $2.7(1.9) \times 10^{6}$ \\
\hline \multirow[t]{2}{*}{$8 \cdot 0$} & 0 & $4 \cdot 0(1 \cdot 2) \times 10^{8}$ & $4.2(0.8) \times 10^{9}$ \\
\hline & 10 & $2 \cdot 1(1.4) \times 10^{6}$ & $6.4(1.8) \times 10^{6}$ \\
\hline
\end{tabular}

The results are expressed as mean $( \pm S D)$.

\section{Effect of normal and patients' sera}

As shown in table I, T. glabrata was inhibited by $2.5 \%$ normal serum, and the yeasts of groups 2,3 and 4 by concentrations between 20 and $50 \%$, whereas group- 5 yeasts were not inhibited. Transferrin alone only inhibited $T$. glabrata at a concentration of $40 \%$ serum-equivalent or greater and the yeasts of groups 2 and 3 at concentrations higher than $50 \%$ with no inhibition of the group 4 and 5 organisms. In liquid cultures of T. glabrata, some growth was observed in the presence of 10 or $20 \%$ serum, but after $48 \mathrm{~h}$ it remained $10^{3}-10^{4} \mathrm{cfu} / \mathrm{ml}$ below the serum-free control cultures; transferrin, however, showed an initial inhibitory action but after $48 \mathrm{~h}$ the viable count was only 10 -fold below the controls (tables III and VII). There was inhibition of growth in inactivated serum, whereas some fungicidal action was observed with the noninactivated samples; however, after incubation for 1 week at $37^{\circ} \mathrm{C}$, both sets of sera exhibited killing of $T$. glabrata with final counts reduced to $10^{4} \mathrm{cfu} /$ $\mathrm{ml}$ below the inoculum. By contrast, transferrin was not fungicidal at $100 \%$ serum-equivalent concentration. Sera stored for up to 4 years at $-20^{\circ}$ or $-70^{\circ} \mathrm{C}$ retained their inhibitory properties, whereas those stored at $4^{\circ} \mathrm{C}$ exhibited a gradual loss of inhibitory activity after storage for a few weeks. Sera from patients with IgG paraprotein and from the patient without detectable $\operatorname{IgA}$ gave results similar to those of normal controls when tested in the radial diffusion assay (table VI). The patient's serum without any detectable globulin but normal transferrin and the sera with $\operatorname{IgM}$ paraproteins showed inhibition equivalent to 40$50 \%$ of that found with normal serum whereas the three cord sera showed a very low inhibitory activity, equivalent to about $10 \%$ of that of normal serum (table VI). Cohn fraction II showed no inhibitory activity when tested at $20 \%$ serumequivalent (table VII). When the concentration of Cohn fraction IV 1 was adjusted to give an IgM concentration equivalent to $10 \%$ serum (IgG $10 \%$, $\operatorname{IgA~} 60 \%$ and transferrin $5 \%$ serum-equivalent), partial inhibition was observed on solid media while in the radial diffusion assay (IgM 100\% serum-equivalent) the inhibition was about $80 \%$ of that of the control serum.

\section{Heat inactivation, dialysis and absorption}

The serum inhibitory factor was completely stable at $56^{\circ} \mathrm{C}$ for up to $2 \mathrm{~h}$, although partial inactivation was obtained beyond $2 \mathrm{~h}$ and this remained unchanged up to $4 \mathrm{~h}$. Non-inactivated 
Table IV. The effect of medium, $p \mathrm{H}$ and metal depletion on yeast growth in the presence or absence of inactivated serum

\begin{tabular}{|c|c|c|c|c|c|c|c|c|c|c|c|c|c|}
\hline \multirow[b]{3}{*}{ Medium } & \multirow[b]{3}{*}{$p \mathrm{H}$} & \multicolumn{12}{|c|}{ Growth $(+)$, partial growth $( \pm) \underset{\text { serum }}{\text { or no growth }(-) \text { of yeasts in the given percentage of }}$} \\
\hline & & \multicolumn{3}{|c|}{ Group 1} & \multicolumn{3}{|c|}{ Group 2} & \multicolumn{3}{|c|}{ Group 3} & \multicolumn{3}{|c|}{ Group 4} \\
\hline & & 0 & 10 & 20 & 0 & 10 & 20 & 0 & 10 & 20 & 0 & 10 & 20 \\
\hline YNB & $7 \cdot 2$ & + & - & - & + & + & _- & + & + & + & + & + & + \\
\hline $\mathrm{YNB}(-\mathrm{Fe})$ & $7 \cdot 2$ & + & - & - & \pm & \pm & - & + & + & + & + & + & + \\
\hline $\mathrm{YNB}(-\mathrm{Mg})$ & $7 \cdot 2$ & \pm & - & - & \pm & \pm & - & + & + & + & + & + & + \\
\hline YNB $(-\mathrm{Cu})$ & $7 \cdot 2$ & + & - & - & $\frac{1}{+}$ & + & - & + & + & + & + & + & + \\
\hline YNB $(-M n)$ & $7 \cdot \overline{2}$ & + & - & - & + & + & - & + & + & + & + & + & + \\
\hline YNB & 4.8 & + & + & + & + & + & + & + & + & + & + & + & + \\
\hline Sabouraud's & $7 \cdot 2$ & + & + & \pm & + & + & + & + & + & + & + & + & + \\
\hline Sabouraud's & $5 \cdot 6$ & + & + & $\frac{1}{+}$ & + & + & + & + & + & + & + & + & + \\
\hline Muller-Hinton & $7 \cdot 3$ & + & - & - & + & + & \pm & + & + & + & + & + & + \\
\hline Brain Heart Infusion & $7 \cdot 3$ & + & - & - & + & + & \pm & + & + & + & + & + & + \\
\hline Water Agar & $7 \cdot 2$ & - & - & - & - & - & $\overline{-}$ & - & + & \pm & \pm & + & + \\
\hline
\end{tabular}

Table V. Effect of metal depletion on the growth of $T$. glabrata in YNB medium

\begin{tabular}{lc|cc}
\hline & & \multicolumn{2}{|c}{ Viable count, cfu (SD)/ml at } \\
\cline { 3 - 4 } $\begin{array}{l}\text { Metal } \\
\text { depleted }\end{array}$ & $\begin{array}{c}\text { Medium } \\
p \mathrm{H}\end{array}$ & $24 \mathrm{~h}$ & $48 \mathrm{~h}$ \\
\hline Iron & 7.2 & $2.0(0.6) \times 10^{8}$ & $1.2(0.3) \times 10^{9}$ \\
& 4.8 & $4.5(1.5) \times 10^{8}$ & $2.3(1.2) \times 10^{10}$ \\
Magnesium & 7.2 & $2.7(1.9) \times 10^{5}$ & $2.0(1.1) \times 10^{4}$ \\
& 4.8 & $1.6(1.2) \times 10^{6}$ & $4.0(1.3) \times 10^{5}$ \\
Manganese & 7.2 & $6.1(1.6) \times 10^{7}$ & $6.0(1.4) \times 10^{8}$ \\
& 4.8 & $8.9(1.1) \times 10^{7}$ & $7.1(1.5) \times 10^{8}$ \\
Copper & 7.2 & $1.0(0.8) \times 10^{8}$ & $8.2(1.2) \times 10^{8}$ \\
& 4.8 & $2.5(1.5) \times 10^{8}$ & $9.3(1.0) \times 10^{8}$ \\
& & & \\
\hline
\end{tabular}

Results with controls are shown in table III.

serum was more inhibitory than inactivated serum (tables VII and VIII). The inhibitory factor was also non-dialysable (table VIII), showing that it has a mol. wt $>10000$. Liquid cultures containing sera absorbed at either $4^{\circ}$ or $37^{\circ} \mathrm{C}$ gave viable counts 10 -fold below the control but approximately 100 fold above the cultures incorporating normal serum (table VII). On solid media very little difference was found between the effects of absorbed and normal sera (table VIII). The inhibitory factor was not absorbed by $C$. albicans when incubated in the same way as for $T$. glabrata.

\section{Sera depleted of transferrin and IgM}

The dilution factors that resulted from depleting the serum of transferrin and $\operatorname{IgM}$ were 17 and 14
Table VI. Inhibition of T. glabrata WCC 083 by serum

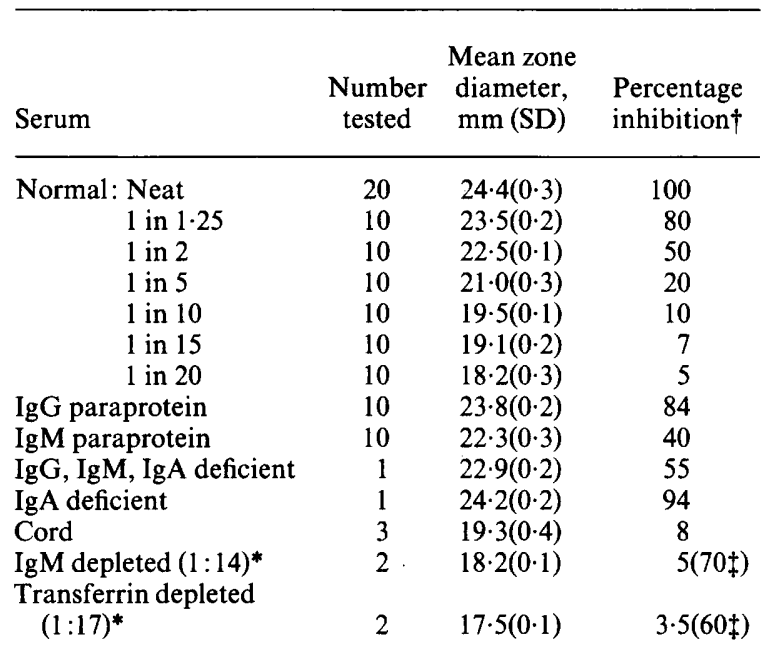

*Final dilution of serum after depletion. $\ddagger$ Undiluted serumequivalent.

$\dagger$ To determine the percentage inhibition obtained with abnormal sera the $\log \%$ serum inhibition of normal serum and serum dilutions in PBS was plotted against the mean zone diameter of inhibition. Neat serum was taken as $100 \%$ inhibition. The graph was analysed statistically using regression line analysis $(\mathrm{r}=0.996)$.

respectively and were estimated from the final concentrations of other proteins. Final concentrations of $<0.001$ and $<0.01 \mathrm{~g} / \mathrm{L}$ for transferrin and IgM, respectively, were obtained. When inhibition by the depleted sera was compared with that caused by the control diluted serum, the contribution of 
Table VII. Effect of serum and serum proteins on $T$. glabrata in liquid culture

\begin{tabular}{|c|c|c|}
\hline \multirow{2}{*}{$\begin{array}{l}\text { YNB medium, } p \mathrm{H} 7 \cdot 2 \text {, with } \\
\text { addition of }\end{array}$} & \multicolumn{2}{|c|}{ Viable count, cfu (SD)/ml at } \\
\hline & $24 \mathrm{~h}$ & $48 \mathrm{~h}$ \\
\hline $\begin{array}{l}10 \% \text { serum (In) } \\
20 \% \text { serum (In) } \\
100 \% \text { serum (In) } \\
10 \% \text { serum (NIn) } \\
100 \% \text { serum (NIn) } \\
10 \% \text { serum (In, A) } \\
10 \% \text { serum (NIn, A) } \\
* 10 \% \text { transferrin } \\
* 20 \% \text { transferrin } \\
* 20 \% \text { Cohn fraction II } \\
{ }^{*} 20 \% \text { Cohn fraction IV } 1\end{array}$ & $\begin{array}{l}2 \cdot 5(1 \cdot 3) \times 10^{6} \\
2 \cdot 1(0 \cdot 5) \times 10^{6} \\
1 \cdot 2(1 \cdot 0) \times 10^{6} \\
1 \cdot 4(0 \cdot 7) \times 10^{6} \\
1 \cdot 1(0 \cdot 5) \times 10^{5} \\
4 \cdot 8(1 \cdot 8) \times 10^{8} \\
3 \cdot 3(1 \cdot 7) \times 10^{8} \\
8 \cdot 3(1 \cdot 3) \times 10^{6} \\
3 \cdot 6(1 \cdot 1) \times 10^{6} \\
1 \cdot 5(0 \cdot 7) \times 10^{9} \\
4 \cdot 5(1 \cdot 5) \times 10^{8}\end{array}$ & $\begin{array}{l}2 \cdot 7(1 \cdot 9) \times 10^{6} \\
6 \cdot 2(0 \cdot 6) \times 10^{5} \\
4 \cdot 2(0 \cdot 9) \times 10^{5} \\
6 \cdot 9(1 \cdot 8) \times 10^{5} \\
7 \cdot 7(1 \cdot 7) \times 10^{4} \\
2 \cdot 2(0 \cdot 9) \times 10^{8} \\
1 \cdot 7(0 \cdot 5) \times 10^{8} \\
5 \cdot 6(1 \cdot 8) \times 10^{8} \\
2 \cdot 0(0 \cdot 8) \times 10^{8} \\
1 \cdot 1(0 \cdot 7) \times 10^{10} \\
1 \cdot 5(1 \cdot 1) \times 10^{9}\end{array}$ \\
\hline
\end{tabular}

In = Inactivated NIn $=$ Non-inactivated $\mathrm{A}=$ Absorbed.

* Serum-equivalent percentage concentrations.

transferrin towards inhibition was estimated to be approximately $40 \%$, that of IgM about $30 \%$, and the remaining $30 \%$ inhibition was attributed to an unidentified component(s) (table VI).

\section{Effect of ferric iron on the inhibitory factor}

Fig. 1 shows the effect of ferric iron on the $p \mathrm{H}$ of the YNB medium. After incubation for $48 \mathrm{~h}$ at $37^{\circ} \mathrm{C}$ (data not shown), the $p \mathrm{H}$ value of the cultures with $10 \%$ serum and no added iron was reduced from $7 \cdot 2$ to $6 \cdot 5$, whereas for those cultures supplemented with iron concentrations above $10 \mu \mathrm{M}$, the $p \mathrm{H}$ value was further reduced to 4.8 and to as low as 2.5 at higher concentrations of iron. For serumfree cultures not supplemented with iron, the lowest

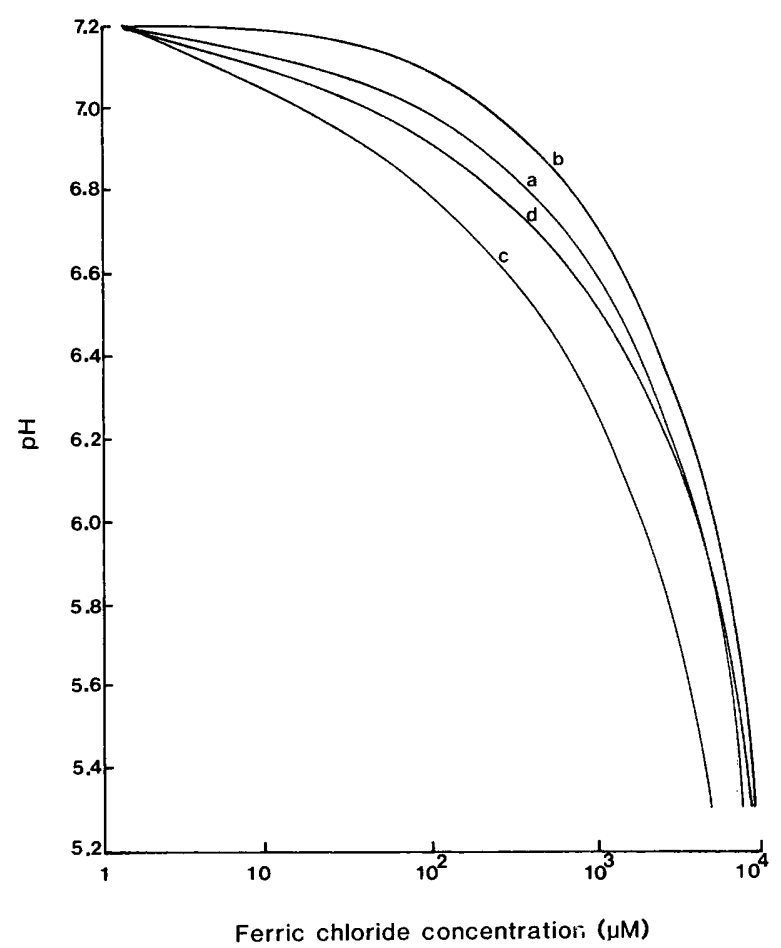

Fig. 1 Effect of ferric chloride on the $p \mathrm{H}$ of the medium. (a) $\mathrm{YNB}, \mathrm{Oh}, 25^{\circ} \mathrm{C}$, (b) $\mathrm{YNB}+10 \%$ serum, $\mathrm{Oh}, 25^{\circ} \mathrm{C}$, (c) $\mathrm{YNB}$, $24 \mathrm{~h}, 37^{\circ} \mathrm{C}$, (d) YNB $+10 \%$ serum, $24 \mathrm{~h}, 37^{\circ} \mathrm{C}$.

$p \mathrm{H}$ value recorded after $48 \mathrm{~h}$ was $3 \cdot 5$. When iron was added to the serum-containing medium, but the medium was not readjusted to the starting $p \mathrm{H}$, the growth observed was never equivalent to that of the serum-free controls. When the $p \mathrm{H}$ was readjusted to $7 \cdot 2$ the viable count was very close to that in normal serum (fig. 2). In the absence of the

Table VIII. Effect of serum in YNB agar on the growth of yeasts at $37^{\circ} \mathrm{C}$ after incubation for $48 \mathrm{~h}$

\begin{tabular}{|c|c|c|c|c|c|c|c|c|c|c|c|c|c|c|}
\hline \multirow{3}{*}{$\begin{array}{l}\text { YNB } \\
p \mathrm{H}\end{array}$} & \multirow{3}{*}{$\begin{array}{c}\text { Serum } \\
\text { treatment }\end{array}$} & \multirow{3}{*}{$\begin{array}{c}\text { Number } \\
\text { of sera }\end{array}$} & \multicolumn{12}{|c|}{ Number of sera showing growth $(+)$, partial growth $( \pm)$ and no growth $(-)$} \\
\hline & & & \multicolumn{3}{|c|}{ Group 1} & \multicolumn{3}{|c|}{ Group 2} & \multicolumn{3}{|c|}{ Group 3} & \multicolumn{3}{|c|}{ Group 4} \\
\hline & & & + & \pm & - & + & \pm & - & + & \pm & - & + & \pm & - \\
\hline $7 \cdot 2$ & Inactivated & 400 & 0 & 12 & 388 & 200 & 80 & 120 & 328 & 40 & 32 & 396 & 4 & 0 \\
\hline 7.2 & Non-inactivated & 100 & 0 & 0 & 100 & 12 & 18 & 70 & 25 & 30 & 45 & 75 & 22 & 3 \\
\hline $7 \cdot 2$ & Dialysed (In) & 10 & 0 & 0 & 10 & 5 & 2 & 3 & 10 & 0 & 0 & 10 & 0 & 0 \\
\hline $7 \cdot 2$ & Absorbed $\left(4^{\circ} \mathrm{C}\right.$, In $)$ & 20 & 0 & 0 & 20 & 12 & 4 & 4 & 17 & 2 & 1 & 19 & 1 & 0 \\
\hline $7 \cdot 2$ & Absorbed $\left(37^{\circ} \mathrm{C}\right.$, In $)$ & 20 & 0 & 2 & 18 & 11 & 4 & 5 & 17 & 3 & 0 & 20 & 0 & 0 \\
\hline $7 \cdot 2$ & Absorbed $\left(4^{\circ} \mathrm{C}, \mathrm{NIn}\right)$ & 20 & 0 & 0 & 20 & 2 & 4 & 14 & 6 & 6 & 8 & 19 & 1 & 0 \\
\hline $7 \cdot 2$ & Absorbed $\left(37^{\circ} \mathrm{C}, \mathrm{NIn}\right)$ & 20 & 0 & 1 & 19 & 12 & 4 & 4 & 17 & 2 & 1 & 19 & 1 & 0 \\
\hline 4.8 & Inactivated & 40 & 25 & 13 & 2 & 34 & 2 & 4 & 38 & 2 & 0 & 40 & 0 & 0 \\
\hline $4 \cdot 8$ & Non-inactivated & 40 & 23 & 13 & 4 & 32 & 5 & 3 & 38 & 2 & 0 & 40 & 0 & 0 \\
\hline
\end{tabular}


inoculum, FN acted as FC, whereas FAC reduced the $p \mathrm{H}$ value to a lesser extent than either of the other compounds. In the inoculated media the effects of the three ferric compounds at concentrations $>250 \mu \mathrm{M}$ were similar; they restored growth of $T$. glabrata in the presence of serum.

\section{Indirect testing of the properties of the inhibitory factor}

When the medium incorporating serum was placed under the dialysis membrane and the organism inoculated either directly on to the membrane or on to a film of water agar on top of the membrane, none of the yeasts tested was fully inhibited and the reduction in the growth of $T$. glabrata was negligible. Full growth was also found when the individual serum proteins were added to medium under the membrane. These findings suggest that no essential growth element was completely bound by proteins under the membrane.

\section{Effect of drugs on the inhibitory factor}

Table II shows the drugs that had no effect on the inhibitory factor and those that reversed inhibition. The concentrations shown are those needed to restore full growth to a level comparable with that found in media without added serum. In the radial diffusion assay the drugs used at the concentrations shown in table II reduced the activity of the inhibitory factor by $>80 \%$.

\section{Discussion}

Our studies indicate that fresh normal human serum inhibits the growth of $T$. glabrata and also, but to a lesser extent, that of Cryptococcus neoformans, $S$. cerevisiae and other yeasts through a more coniplicated mechanism than has been reported previously. Transferrin appears to account for approximately $40 \%$ of the total inhibitory effect and other metal-chelating proteins were not implicated; other serum components that were nondialysable, heat stable and which could be partly absorbed by live cells of $T$. glabrata, were responsible for the residual inhibition of growth. These components were found to be sensitive to $p \mathrm{H}$ changes, being partially inactivated between $p \mathrm{H} 7.6$ and 8.0 , or 6.9 and 6.0 , with complete inactivation at and below $p \mathrm{H} 5 \cdot 0$. Fig. 1 demonstrates the marked $p \mathrm{H}$-value reduction that follows the addition of ferric iron to YNB media; ferric iron hydrolyses to form complexes, the hydrolysis being equivalent to acid dissociation of $\mathrm{H}_{2} \mathrm{O}$ with the

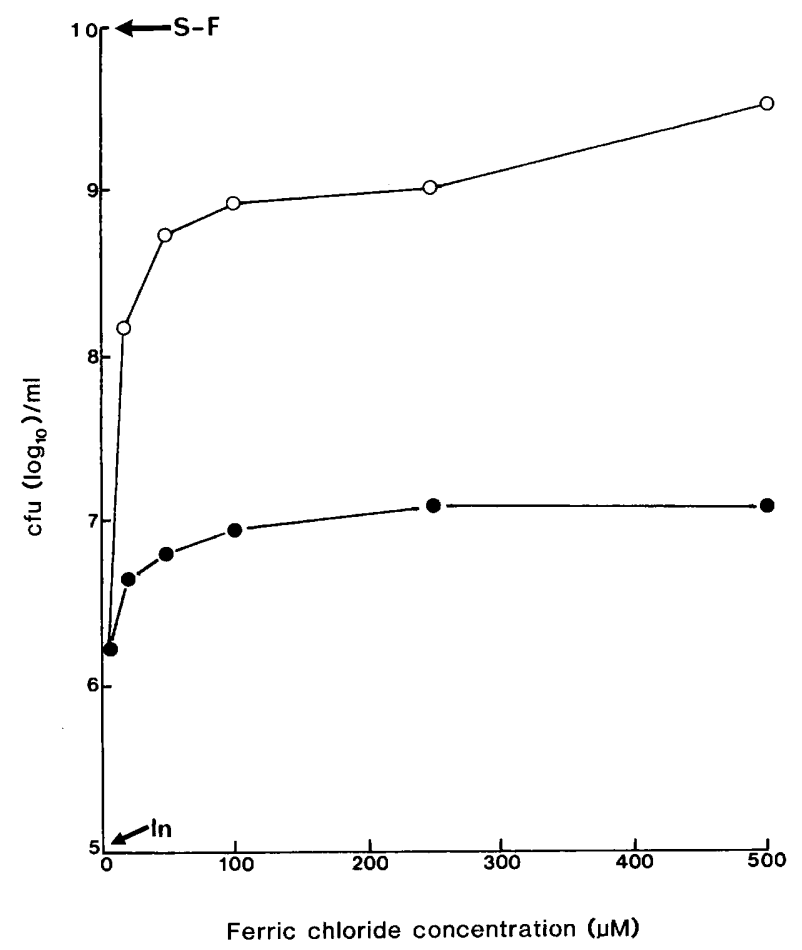

Fig. 2. Effect of ferric chloride on the viable count of T. glabrata in $\mathrm{YNB}, p \mathrm{H} 7 \cdot 2,+10 \%$ serum after incubation for $48 \mathrm{~h}$ at $37^{\circ} \mathrm{C}$; (O) $\mathrm{pH}$ left unchanged. (O) $\mathrm{pH}$ readjusted to $7 \cdot 2 . \mathrm{S}-\mathrm{F}=$ serumfree culture, $\mathrm{In}=$ inoculum.

production of hydrogen ions (Cotton and Wilkinson, 1972). Furthermore, fig. 2 shows that if the effect of iron on $p \mathrm{H}$ is not taken into account, then transferrin could be considered to be the only inhibitor in human serum. However, by readjustment of the medium $p \mathrm{H}$ to $7 \cdot 2$, an inhibitory effect was still observed. Inhibition could be demonstrated in sera stored at $-20^{\circ} \mathrm{C}$ or $-70^{\circ} \mathrm{C}$ for up to 4 years but there was gradual reduction in inhibition when sera were stored at $4^{\circ} \mathrm{C}$ for more than a few weeks.

By testing the various serum fractions and patients' sera, it was found that none of the components of the inhibitory factor was present in the purified albumin or $\gamma$-globulin fractions of serum. The inhibitory factor consisted of a combination of transferrin, IgM and probably some other protein present in Cohn fraction IV 1. These findings were confirmed by testing sera depleted of transferrin or IgM. The poor inhibition obtained with the cord sera was further support for the role of transferrin and IgM since the transferrin in cord blood and newborn blood is nearly fully saturated with iron (Caroline et al, 1969) and the IgM level is very low or undetectable (Hobbs, 1969). 
Various factors predispose to fungal overgrowth, as reviewed by Seelig $(1966 a, b ; 1968)$ and Warnock (1980), and our findings suggest that some antimicrobial agents such as tetracyclines, quinolones, sulphamethoxazole and subinhibitory concentrations of antifungal agents may also contribute by protecting $T$. glabrata from inhibitory serum components. This may be either by direct attachment on to the inhibitory factor, reaction with the inhibitory factor's substrate, such as iron, or attachment to the organism's receptors for the inhibitory factor. The binding of drugs to serum proteins is believed to be due mainly to an interaction between the drug and serum albumin. However, other serum proteins, including enzymes, have been shown to interact with some drugs, e.g., tetracycline (Kornguth and Kunin, 1976). Transferrin and IgM have not previously been shown to interact with any of the drugs which we found to neutralise the inhibitory factor. Tetracycline has

\section{REFERENCES}

Caroline L, Rosner F, Kozinn P J 1969 Elevated serum iron, low unbound transferrin and candidiasis in acute leukemia. Blood 34: 441-451.

Caroline L, Taschdjian C L, Kozinn P J, Schade A L 1964 Reversal of serum fungistasis by addition of iron. Journal of Investigative Dermatology 42: 415-419.

Cotton F A, Wilkinson G (eds) 1972 Advanced inorganic chemistry, a comprehensive text, 3rd edn. Wiley, New York, pp. 863-867.

Esterly N B, Brammer S R, Crounse R G 1967 The relationship of transferrin and iron to serum inhibition of Candida albicans. Journal of Investigative Dermatology 49: 437-442.

Greenberger N J 1973 Effects of antibiotics and other agents on the intestinal transport of iron. American Journal of Clinical Nutrition 26: 104-112.

Hobbs J R 1969 Primary immune paresis. In: Adinolfi M (ed). Immunology and development, Heinemann, London, p. 114.

Howard D H, Otto V 1967 The intracellular behaviour of Torulopsis glabrata. Sabouradia 5: 235-239.

King R D, Khan H A, Foye J C, Greenberg J H, Jones H E 1975 Transferrin, iron, and dermatophytes. I. Serum dermatophyte inhibitory component definitively identified as unsaturated transferrin. Journal of Laboratory and Clinical Medicine 86: 204-212.

Kornguth M L, Kunin C M 1976 Binding of antibiotics to the human intracellular erythrocyte proteins hemoglobin and carbonic anhydrase. Journal of Infectious Diseases 133: 185193. been shown to chelate iron (Greenberger, 1973), and this effect might account for the neutralisation of transferrin activity if the organism is able to remove iron from tetracycline. The reversal of inhibition by IgM may be either by a direct binding to the drug or by the action of the drug on the surface of the organism, which will disturb the configuration of the membrane, or cell wall, in such a manner that the binding of IgM on to the organism is inhibited. The third component of the inhibitory factor, which we could not characterise, was responsible for $30 \%$ of the inhibition, and as it exhibited similar properties to IgM, we conclude that it may be another serum protein.

We thank Dr P. G. Riches and Mr D. E. Perry for supplying the abnormal sera and for their help and advice. We also thank Miss C. Farnham for typing the manuscript. M. A. Petrou was supported by a grant from the Andrew and Elisabeth Bostic Fund. Finally, we thank Professor S. Selwyn for his advice during the preparation of the manuscript.

Otto V, Howard D H 1976 Further studies on the intracellular behaviour of Torulopsis glabrata. Infection and Immunity 14: 433-438.

Petrou M A, Rogers T R 1985 A comparison of the activity of mepartricin and amphotericin B against yeasts. Journal of Antimicrobial Chemotherapy 16: 169-178.

Schade A L, Caroline L 1946 An iron-binding component in human blood plasma. Science 104: 340-341.

Schultze H E, Heremans, J F (eds) 1966 Molecular biology of human proteins, vol. 1. Elsevier, Amsterdam.

Seelig M S $1966 a$ The role of antibiotics in the pathogenesis of Candida infections. American Journal of Medicine 40: 889917.

Seelig M S $1966 b$ Mechanisms by which antibiotics increase the incidence and severity of candidiasis and alter the immunological defenses. Bacteriological Reviews 30: 442-459.

Seelig M S 1968 The rationale for preventing antibacterialinduced fungal overgrowth. Medical Times 96: 689-710.

Summers D F, Hasenclever H F 1964 In-vitro inhibition of yeast growth by mouse ascites fluid and serum. Journal of Bacteriology 87 : 1-7.

Warnock D W 1982 Immunological and other defects predisposing to fungal infection in the compromised host. In: Warnock D W, Richardson M D (eds) Fungal infection in the compromised patient. Wiley, Chichester, pp. 29-47.

Whicher J T, Perry D E 1984 Nephelometric methods. In: Butt W R (ed). Practical immunoassay. Marcel Dekker, New York, pp. 117-177.

Wickerham L J 1951 Taxonomy of yeasts. Technical Bulletin 1029, U.S. Department of Agriculture, Washington D.C. 